Article

\title{
Synergistic Mechanisms Underlie the Peroxide and Coagent Improvement of Natural-Rubber-Toughened Poly(3-hydroxybutyrate-co-3-hydroxyvalerate) Mechanical Performance
}

\author{
Xiaoying Zhao ${ }^{1}{ }^{\oplus}$, Katrina Cornish ${ }^{2,3}$ and Yael Vodovotz ${ }^{1, *}$ \\ 1 The Ohio State University, Department of Food Science and Technology, 2015 Fyffe Road, \\ Columbus, OH 43210, USA; zhao.1630@osu.edu \\ 2 The Ohio State University, Department of Horticulture and Crop Science, 1680 Madison Avenue, \\ Wooster, OH 44691, USA; cornish.19@osu.edu \\ 3 The Ohio State University, Department of Food, Agricultural and Biological Engineering, 1680 Madison \\ Avenue, Wooster, OH 44691, USA \\ * Correspondence: vodovotz.1@osu.edu; Tel.: +01-614-292-0218
}

Received: 23 January 2019; Accepted: 19 March 2019; Published: 26 March 2019

check for updates

\begin{abstract}
Poly(3-hydroxybutyrate-co-3-hydroxyvalerate) (PHBV) is a promising bio-based and biodegradable thermoplastic with restricted industrial applications due to its brittleness and poor processability. Natural rubber (NR) has been used as a toughening agent, but further physical improvements are desired. In this study, rubber toughening efficiency was significantly improved through the synergistic use of a trifunctional acrylic coagent and an organic peroxide during reactive extrusion of PHBV and NR. The rheological, crystallization, thermal, morphological, and mechanical properties of PHBV/NR blends with 15\% rubber loading were characterized. The peroxide and coagent synergistically crosslinked the rubber phase and grafted PHBV onto rubber backbones, leading to enhanced rubber modulus and cohesive strength as well as improved PHBV-rubber compatibility and blend homogeneity. Simultaneously, the peroxide-coagent treatment decreased PHBV crystallinity and crystal size and depressed peroxy-radical-caused PHBV degradation. The new PHBV /NR blends had a broader processing window, 75\% better toughness (based on the notched impact strength data), and $100 \%$ better ductility (based on the tensile elongation data) than pristine PHBV. This new rubber-toughened PHBV material has balanced mechanical performance comparable to that of conventional thermoplastics and is suitable for a wide range of plastic applications.
\end{abstract}

Keywords: poly(3-hydroxybutyrate-co-3-hydroxyvalerate) (PHBV); bioplastic; natural rubber; reactive extrusion; toughening

\section{Introduction}

Currently, more than $90 \%$ of plastics are petroleum-based and non-biodegradable [1], and their wide industrial use is of significant environmental concern. Development of biodegradable polymers from renewable resources is needed to lessen oil dependence, reduce environmental pollution, and improve global sustainability. Polyhydroxyalkanoates (PHAs) are biodegradable aliphatic polyesters produced through bacterial fermentation of sugars or lipids [2]. PHA properties can be customized to meet the final use requirements by adjusting the monomer unit composition [3], microorganism, and carbon source used in fermentation [4]. PHA versatility provides a wide range of properties for various applications [5], contributing to the predicted market growth from about 51,150 tonnes in 2010 to 405,100 tonnes by 2020 [6]. 
One of the most studied PHAs is polyhydroxybutyrate (PHB), obtained from polymerization of 3-hydroxybutyrate monomers. It has properties similar to polypropylene (PP) but is stiffer and more brittle-characteristics which prevent its widespread industrial use. Incorporation of poly(3-hydroxyvalerate) to form poly(3-hydroxybutyrate-co-3-hydroxyvalerate) (PHBV), which has improved flexibility and toughness, has various promising applications in the packaging, biomedical, agricultural, automotive, and construction industries $[7,8]$. Yet, despite these enhancements, PHBV remains brittle, has an unacceptably narrow processing window, and is expensive [9]. PHBV brittleness is mainly caused by its high degree of crystallinity and large spherulites [10,11], which can be reduced by plasticization [12], incorporation of nucleating agents to reduce spherulite size [13,14], chemical modification, and blending with flexible polymers [15].

Incorporation of natural rubber (NR) into PHBV through melt blending is an industrially and economically viable route to improve PHBV flexibility and toughness. NR is a promising toughening agent due to its ductility, elasticity, availability, and low cost [16]. NR's renewability and biodegradability can also help maintain the "green" nature of PHBV [16]. The rubber toughening mechanisms can be explained by several theories. According to void toughening theory, rubber particles concentrate stress then go through cavitation, releasing volume strain energy and reducing the resistance of the polymer matrix to volumetric expansion [17-19]. The matrix then undergoes shear yielding and/or crazing, which absorbs most of the fracture energy [17-19]. In contrast, stress field theory suggests that rubber particles influence the crystallization behavior of the polymer matrix and introduce a layer of oriented crystalline lamellae perpendicular to the rubber/matrix interface [20,21]. The lamellae are connected by hydrogen-bonded planes which are perpendicular to the lamellae and have low slip resistance [20]. When impacted by an outside force, the inter-particle regions deform through crystalline slip, causing shearing of the surrounding crystalline regions and rotation of the crystals, enabling more energy absorption and resulting in improved toughness [20]. This is also the concept behind filler-induced toughening of polymers [22].

In both theoretical models, NR's toughening efficacy depends on interfacial adhesion between NR and PHBV, rubber particle size and dispersion, inter-particle distance (ligament thickness), rubber modulus, matrix properties, processing conditions, and other factors [17]. Generally, optimal particle size, homogeneous rubber dispersion, thin ligaments, and good rubber/matrix adhesion are required for maximum toughness. Reactive blending has been used for rubber-toughened thermoplastics by improving blend morphology and compatibility between rubber and plastic [23]. This process selectively cures rubber during its intimate melt mixing with a thermoplastic [24], preventing either phase from coalescing [25] and leading to excellent rubber dispersion in the plastic matrix [26]. In addition, crosslinking allows rubber to reach high strains under stress through the formation of strong fibrils [17]. Crosslinking also enhances interconnectivity among stress fields around rubber particles, allowing for easier stress transfer $[17,27]$. Covalent bonds between the rubber and plastic matrixes clearly would overcome interfacial repulsion and improve interfacial adhesion $[28,29]$.

Peroxide-induced crosslinking of rubber and other polymers is an effective non-sulfurous crosslinking method acceptable in food contact applications [30]. Peroxides produce strong free radicals as they break down when exposed to heat during melt blending [30]. The radicals abstract $\mathrm{H}$ atoms from methylene groups on polymer chains and initiate formation of $\mathrm{C}-\mathrm{C}$ crosslinks between very different, normally incompatible polymers [30]. Reactive blending of PHB and PBS (polybutylene succinate), with dicumyl peroxide (DCP) crosslinker, reduced PBS particle size and enhanced interfacial adhesion between the two polymers [31]. The PHB/PBS blends had improved tensile and impact strength over pristine PHB [31]. Similarly, PLA flexibility was improved by DCP-initiated reactive blending with NR [28]. Here, a continuous crosslinked NR phase was dispersed in the PLA matrix and the two phases had good interfacial adhesion (PLA grafted onto NR during melt-blending) [28]. However, peroxide-induced crosslinking lacks chemical selectivity, and competition between in situ compatibilization/crosslinking and free-radical-caused polymer degradation makes it difficult to control blend properties [32]. The balance between productive and non-productive competing reactions 
is affected by the polymer microstructure and the presence of dissolved oxygen and hydrogen donors (anti-oxidants, fatty acids, oils, etc.) in the formulation [32]. As most of the non-productive reactions are kinetically favored, productive reactions advancing effective crosslink formation can occur only if there is a very high concentration of reactive sites on the polymer backbone [32].

Coagents are typically multifunctional monomers highly reactive with free radicals. Coagents can be used in peroxide-induced crosslinking to shift the reaction balance toward productive reactions by introducing a high concentration of reactive sites. These reactive sites result in efficient use of the peroxide-derived radicals and reduce the occurrence of deleterious side reactions [32], leading to increased crosslink density (Figure 1). The addition of coagents triallyl cyanurate (TAC), trimethylol propane triacrylate (TMPTA), and N,N'-m-phenylene dimaleimide (MPDM) in reactive blending of polypropylene (PP) and ethylene octene copolymer (EOC) increased the crosslink density of EOC and decreased the thermal degradation of PP [29]. The coagents limited deleterious PP chain scissions by reacting with PP macroradicals, forming a more stable polymer radical [29]. Also, the coagents reduced PP crosslinking by grafting onto PP polymer chains, which inhibited spherulite growth, decreased PP crystallinity, and improved PP toughness [29]. Similarly, the addition of coagent difunctional maleimide stabilized PP macroradicals and unsaturated polyester (UP) melts, localized the free radical reactions to PP/UP interfaces [33], maximized the formation of grafted copolymer, and improved blend properties [33].

In our previous study, peroxide alone was used during reactive blending of PHBV and NR to improve blend compatibility and morphology [34]. Blends containing 10-15\% NR provided an optimal combination of processing and mechanical properties [35]. However, further improvements in blend strength and toughness are desired to obtain materials with balanced mechanical properties for broadened industrial applications. Therefore, a coagent was synergistically used with peroxide in this study to further improve the blend mechanical performance. The effect of the coagent on the thermal, crystallization, morphological, and mechanical properties of PHBV /NR blends was investigated. In our previous work [34,35], we investigated the effect of peroxide $(0.15-0.45 \mathrm{wt} \%)$, coagent $(0-0.63 \mathrm{wt} \%)$, and rubber (10-20 wt \%) concentrations on the mechanical properties of PHBV/NR blends. The optimal formulation of the blends was $0.45 \mathrm{wt} \%$ peroxide, $0.63 \mathrm{wt} \%$ coagent, and $15 \mathrm{wt} \% \mathrm{NR}$, and this was used to fabricate blends of PHBV and NR in this work.

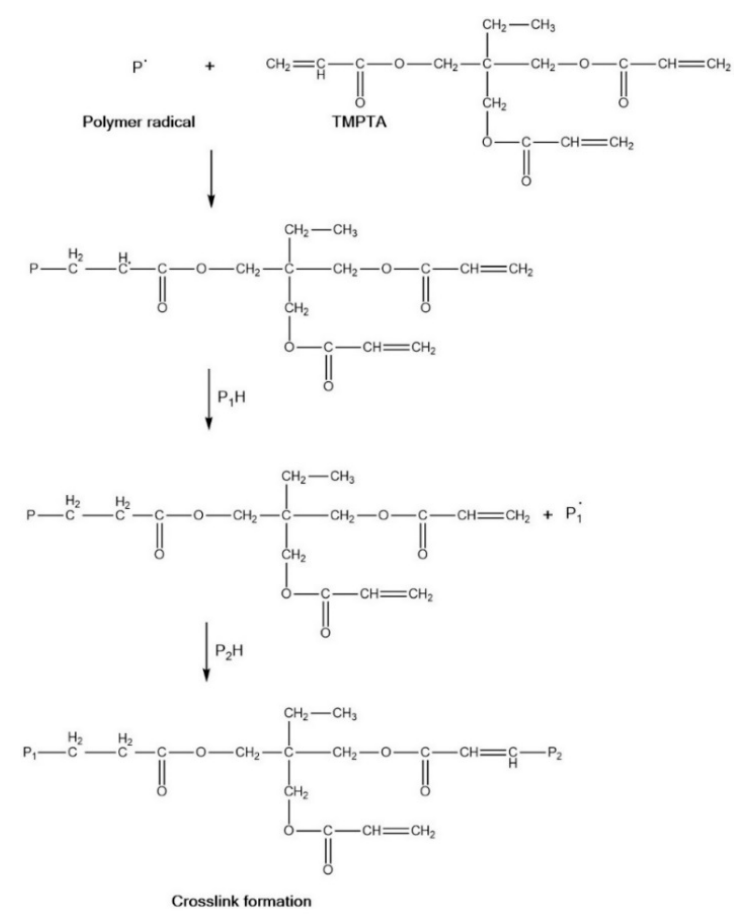

Figure 1. Trimethylol propane triacrylate (TMPTA) coagent reacts with polymer radicals [36,37]. 


\section{Materials and Methods}

\subsection{Materials}

NR, which was Standard Indonesian Rubber-20 (SIR-20) of constant viscosity, was purchased from CentroTrade LLC (Wadsworth, OH, USA). Peroxide Luperox 101XL45 (2,5-Bis (tert-butylperoxy)-2,5-dimethylhexane) and coagent (trimethylolpropane triacrylate, TMPTA) were purchased from Sigma-Aldrich (St. Louis, MO, USA). PHBV with approximately 2 mol \% hydroxyvalerate (HV) content was purchased from Tianan Biological Material Co. (Ningbo, China). Both rubber and peroxide were used as received. PHBV pellets were vacuum-dried for $24 \mathrm{~h}$ at $60{ }^{\circ} \mathrm{C}$ before use.

\subsection{Methods}

\subsubsection{Blend Preparation}

Pre-dried PHBV, NR, peroxide Luperox 101XL45, and coagent TMPTA were premixed and fed into a pre-heated Leistritz ZSE-27 twin-screw extruder (Somerville, NJ, USA) for blending. The reactive blending was conducted at $60 \mathrm{rpm}$, with a reverse compounding temperature from 180 to $145^{\circ} \mathrm{C}$ (Table 1). The formulae of the blends are shown in Table 2. The blends of PHBV and NR, with or without peroxide/coagent treatment, are generally referred to as PHBV/NR blends in this study.

Table 1. Barrel temperatures of poly (3-hydroxybutyrate-co-3-hydroxyvalerate) (PHBV)/natural rubber (NR) reactive extrusion.

\begin{tabular}{cc}
\hline Heaters & Temperatures $\left({ }^{\circ} \mathbf{C}\right)$ \\
\hline 1 (Below hopper) & 180 \\
2 & 175 \\
3 & 175 \\
4 & 170 \\
5 & 170 \\
6 & 160 \\
7 & 160 \\
8 & 155 \\
9 & 150 \\
$10($ Die $)$ & 145 \\
\hline
\end{tabular}

Table 2. PHBV and PHBV/NR blends obtained from extrusion melt blending.

\begin{tabular}{cccc}
\hline Sample & PHBV/NR (wt/wt) & Peroxide (wt \%) & Coagent (wt \%) \\
\hline PHBV & $100: 0$ & 0 & 0 \\
PHBV/NR & $85: 15$ & 0 & 0 \\
PHBV/NR/P & $85: 15$ & 0.45 & 0 \\
PHBV/NR/P/C & $85: 15$ & 0.45 & 0.63 \\
\hline
\end{tabular}

\subsubsection{Gel Fraction Measurement}

Pelleted samples were dissolved in chloroform at $60{ }^{\circ} \mathrm{C}$ for $24 \mathrm{~h}$. The turbid solutions were centrifuged at $4000 \mathrm{rpm}$ for $10 \mathrm{~min}$. The gels on the top of the centrifuged solutions were collected, rinsed by chloroform five times, and dried. The gel fractions $\left(G_{f}\right)$ were calculated as follows: $G_{f}=m_{1} / m_{0} \times 100 \%$, where $m_{0}$ is the initial weight of the samples and $m_{1}$ is the weight of the dried residue obtained after chloroform extraction [31].

\subsubsection{Rheological Characterization}

The rheological behavior of the materials was analyzed using a TA Instrument Ares LSII rheometer (New Castle, DE, USA). Rheological determinations were performed at $175{ }^{\circ} \mathrm{C}$ using a $25 \mathrm{~mm}$ parallel 
plate system. Each disk sample, with a thickness of $1 \mathrm{~mm}$ and diameter of $25 \mathrm{~mm}$, was equilibrated for $5 \mathrm{~min}$ before the gap was set to the testing position of approximately $0.9 \mathrm{~mm}$ or until the top plate made contact with the upper surface of the sample. The complex viscosity, storage modulus $\left(G^{\prime}\right)$, and loss modulus $\left(G^{\prime \prime}\right)$ were measured with increasing frequency from 0.1 to $100 \mathrm{rad} \mathrm{s}^{-1}$ at $0.3 \%$ strain [38-40].

\subsubsection{Scanning Electron Microscopy (SEM)}

The fracture surfaces of the samples from notched impact testing were visualized using a Quanta 200 (FEI Inc., Hillsboro, OR, USA) scanning electron microscope (SEM). The samples were observed after mechanical failure at ambient temperature. Samples were coated with a $10 \mathrm{~nm}$ layer of gold using a Cressington 108 sputter coater (Watford, UK).

\subsubsection{Mechanical Characterization}

Pellets of PHBV/NR blends were injection molded into mechanical testing specimens and vacuum-dried for $24 \mathrm{~h}$ at $60{ }^{\circ} \mathrm{C}$ prior to testing. Tensile testing was conducted according to ASTM D638-08 using an Instron 5542 with the Bluehill v. 2.17 software package (Instron Corp., Norwood, MA, USA). Dumbbell-shaped samples $\left(165.0 \times 19.0 \times 7.0 \mathrm{~mm}^{3}\right)$ with a grip distance of $115 \mathrm{~mm}$ were prepared, and a crosshead speed of $5 \mathrm{~mm} \cdot \mathrm{min}^{-1}$ at room temperature was used. The flexural properties were determined according to ASTM D790-15. The test sample dimensions were $127.0 \times 12.7 \times 3.2 \mathrm{~mm}^{3}$. The $1 \%$ secant modulus, which represents the stress-strain ratio at the point on the curve that corresponds to the point of extension that is $1 \%$ of the initial sample length, was determined to evaluate the flexibility of the samples. Notched impact tests were conducted according to ASTM D256-10. Notched impact samples $\left(63.5 \times 12.7 \times 0.32 \mathrm{~mm}^{3}\right.$ with a $22.5^{\circ}$ notch $)$ were tested using an impact tester from Tinius Olsen (Horsham, PA, USA). The reported standard deviation (SD) values were calculated from at least three samples. Statistical analyses were performed using JMP 10.0 (Marlow, Buckinghamshire, UK). Significant differences ( $p$-values $<0.05$ ) in mechanical data between PHBV and its blends were determined using one-way analysis of variance (ANOVA) and the Tukey HSD method.

\subsubsection{Thermogravimetric Analysis (TGA)}

A TA Instrument Discovery TGA 550 (New Castle, DE, USA) was used to study the thermal decomposition properties of the materials. Samples were heated under nitrogen from room temperature to $500{ }^{\circ} \mathrm{C}$ at $20^{\circ} \mathrm{C} \cdot \mathrm{min}^{-1}$. Extrapolated onset $\left(T_{\mathrm{o}}\right)$ and peak $\left(T_{\mathrm{p}}\right)$ degradation temperatures were taken from the weight loss and derivative thermograms, respectively.

\subsubsection{Differential Scanning Calorimetry (DSC)}

The thermal transitions of the materials were investigated using a previously described procedure [38,41] with a TA Instrument Discovery DSC 2500 (New Castle, DE, USA). The samples were first heated from room temperature to $200{ }^{\circ} \mathrm{C}$ at $10{ }^{\circ} \mathrm{C} \cdot \mathrm{min}^{-1}$, annealed at $200{ }^{\circ} \mathrm{C}$ for $4 \mathrm{~min}$ to remove the thermal history, subsequently cooled to $-85^{\circ} \mathrm{C}$, held for $4 \mathrm{~min}$, and reheated from -85 to $200{ }^{\circ} \mathrm{C}$ at $10^{\circ} \mathrm{C} \cdot \mathrm{min}^{-1}$. The onset and peak crystallization temperatures $\left(T_{\mathrm{c}(\text { onset })}\right.$ and $\left.T_{\mathrm{c}(\text { peak })}\right)$ were determined from the cooling scans. The glass transition temperature $\left(T_{\mathrm{g}}\right)$, melting temperature $\left(T_{\mathrm{m}}\right)$, enthalpy of fusion $\left(\Delta H_{\mathrm{m}}\right)$, and degree of crystallinity $\left(X_{\mathrm{c}}\right)$ were determined from the second heating scans. $T_{\mathrm{m}}$ was determined at the peak value of the endotherms and $T_{\mathrm{g}}$ at the midpoint of the heat capacity changes $\left(0-20 \mathrm{~J} \mathrm{~g}^{-1}\right) . \Delta H_{\mathrm{m}}$ was determined from the area under the endotherms using TRIOS Software v4.1.1.33073. The relative crystallinity of the blends was obtained by dividing $\Delta H_{\mathrm{m}}$ by the enthalpy value of a theoretically $100 \%$ crystalline PHBV $\left(146 \mathrm{~J} \cdot \mathrm{g}^{-1}\right)$ taken from literature values [42-45]. 


\subsubsection{X-ray Diffraction (XRD)}

XRD patterns of the samples were obtained using a Rigaku Miniflex $600 \mathrm{X}$-ray diffractometer (Woodlands, TX, USA) operating at $40 \mathrm{kV}$ and $15 \mathrm{~mA}$. Data were collected in the range of $2 \theta=5^{\circ}-60^{\circ}$ at $2^{\circ} \cdot \mathrm{min}^{-1}$. Crystal interplanar distances (d-spacing) (three families of lattice planes (020), (110), and (121) studied) were calculated using Bragg's relationship [46,47]: $\lambda=2 d \times \sin \theta$, where $d$ is the $\mathrm{d}$-spacing, $\lambda$ is the $\mathrm{X}$-ray wavelength $(1.5406 \AA)$, and $\theta$ is the scattering angle. The crystal size was calculated by the equation $D=\frac{K \times \lambda}{\beta \times \cos \theta}$, where $D$ is the crystal size, $\lambda$ is the $X$-ray wavelength, $\beta$ is the full width at half-maximum (FWHM) of the peak, $\theta$ is the scattering angle, and $K$ is the Scherrer constant (0.9) [48].

\subsubsection{Fourier Transform Infrared Spectroscopy (FTIR)}

FTIR absorption spectra of the crosslinked part (gel from the chloroform extraction) of the blends were obtained using an Agilent 4500a portable FTIR spectrometer (Santa Clara, CA, USA) in attenuated total reflectance (ATR) mode, with $4 \mathrm{~cm}^{-1}$ resolution, 64 scans, and spectral wavelengths ranging from 650 to $4000 \mathrm{~cm}^{-1}$.

\subsubsection{Proton Nuclear Magnetic Resonance $\left({ }^{1} \mathrm{H}\right.$ NMR) Spectroscopy}

The chemical structures of the uncrosslinked part (solution from chloroform extraction after removal of the gel) of the blends were characterized by ${ }^{1} \mathrm{H}$ NMR (Bruker AC-P $400 \mathrm{MHz}$ spectrometer) at room temperature with $\mathrm{CDCl}_{3}$ as a solvent. Chemical shifts were referenced to the residual proton peak of $\mathrm{CDCl}_{3}$ at $7.24 \mathrm{ppm}$.

\section{Results and Discussion}

\subsection{Crosslink Formation during Reactive Blending}

The crosslinking effect of the peroxide and coagent during the reactive blending of PHBV and NR is shown in Table 3. Of note, pristine PHBV, which did not go through the melt procedure, did not form a gel (crosslinks), as was expected, due to the lack of networks in its macro-molecular structure. Pristine NR had 1.5\% gel, and extrusion did not break down the gel. The slightly higher gel content observed in extruded NR than in pristine NR may be caused by rubber aging under heat and oxygen [49]. Unexpectedly, no gel was present in PHBV/NR blend, indicating that the PHBV phase broke down the pre-existing NR gel and prevented the heat/oxygen-caused rubber aging/crosslinking during the melt blend formation. Both PHBV/NR/P and PHBV/NR/P/C contained gels mainly formed by the rubber phase, as indicated by the TGA thermograms and FTIR spectra of the gels (Figure 6; Figure 10 , and discussed later). The PHBV/NR/P/C blend had a gel fraction similar to its rubber content, suggesting that the highly reactive coagent molecules fully crosslinked NR, potentially by restricting competing deleterious reactions through efficient use of peroxide-derived radicals. In contrast, the gel fraction of PHBV /NR/P (6\%) was much lower than its rubber content $(15 \%)$ but higher than the corresponding gel fraction of the incorporated rubber in the blend, indicating that peroxide alone, at 3 phr loading, only crosslinked a fraction of the rubber phase in this blend. It is worth mentioning that instead of synergistically using the coagent, increasing the loading of peroxide alone can also increase the NR crosslink density. However, the use of peroxide may be counterproductive because it can cause polymer chain scission, as discussed later. 
Table 3. Gel fractions of pristine PHBV, pristine NR, and PHBV/NR blends determined by chloroform extraction.

\begin{tabular}{ccccccc}
\hline Samples & Pristine PHBV & Pristine NR & Extruded NR * & PHBV/NR & PHBV/NR/P & PHBV/NR/P/C \\
\hline Gel $(\mathrm{wt} \%)$ & 0 & $1.56 \pm 0.04$ & $3.91 \pm 0.02$ & 0 & $6.0 \pm 0.71$ & $13.0 \pm 0.35$ \\
\hline \multicolumn{5}{c}{ * NR alone was extruded under the same conditions as the PHBV/NR blend extrusion. }
\end{tabular}

\subsection{Rheological Properties}

The formation of crosslinks during reactive blending significantly affected the rheological properties of PHBV in the blends. The viscosity of pristine PHBV decreased with peroxide treatment, mainly due to peroxide-caused polymer degradation through chain scission, which has been observed in peroxide-assisted reactive extrusion of polyolefin graft copolymers and peroxide-induced reactive blending of biodegradable polyesters poly- $\varepsilon$-caprolactone (PCL) and PHB [50,51]. PHBV/NR/P was more viscous and had more significant shear thinning behavior than PHBV/NR and pristine PHBV (Figure 2), suggesting (1) enhanced chain entanglements caused by peroxide-initiated crosslinking of NR in the blends [52], as supported by the higher gel content, and (2) covalent PHBV/NR grafting [53-55] (demonstrated by FTIR and NMR analysis and discussed below). This observation differs from a previous study where peroxide treatment decreased the viscosity of $\mathrm{PP} /$ ethylene-propylene rubber (EPR)/polyethylene (PE) blends by causing polymer chain scission [36]. The viscosity increase in $\mathrm{PHBV} / \mathrm{NR} / \mathrm{P}$ in this study indicated that peroxide crosslinking of NR more than compensated for any polymer chain scission [52]. PHBV/NR/P/C was more viscous than $\mathrm{PHBV} / \mathrm{NR} / \mathrm{P}$ (Figure 1), reflecting its greater crosslink density (gel content, Table 3 ) in the presence of coagent. The coagent played a triple role in this blend: (1) it promoted efficient NR crosslinking by covalently binding to NR polymer chains and forming a more stable NR polymer radical (Figure 1), which was more likely to form an NR-NR crosslink with another NR radical before deleterious scission or dehydrohalogenation reactions occurred [56]; (2) it crosslinked PHBV and NR to form copolymers (supported by FTIR and NMR results), reducing interfacial tensions and incompatibility between the two phases [36]; (3) during the melt blending process, peroxy radicals attacked the unstable tertiary $\mathrm{H}$ of PHBV molecules and caused chain cleavage, $\beta$ chain scission, and chain branching $[57,58]$, resulting in the formation of low-molecular-weight polymer chains [59-61] reflected by the decreased viscosity. It has been reported that a coagent can suppress this thermally enhanced degradation process by stabilizing and reacting with PHBV macroradicals (Figure 9) [52,57,62].

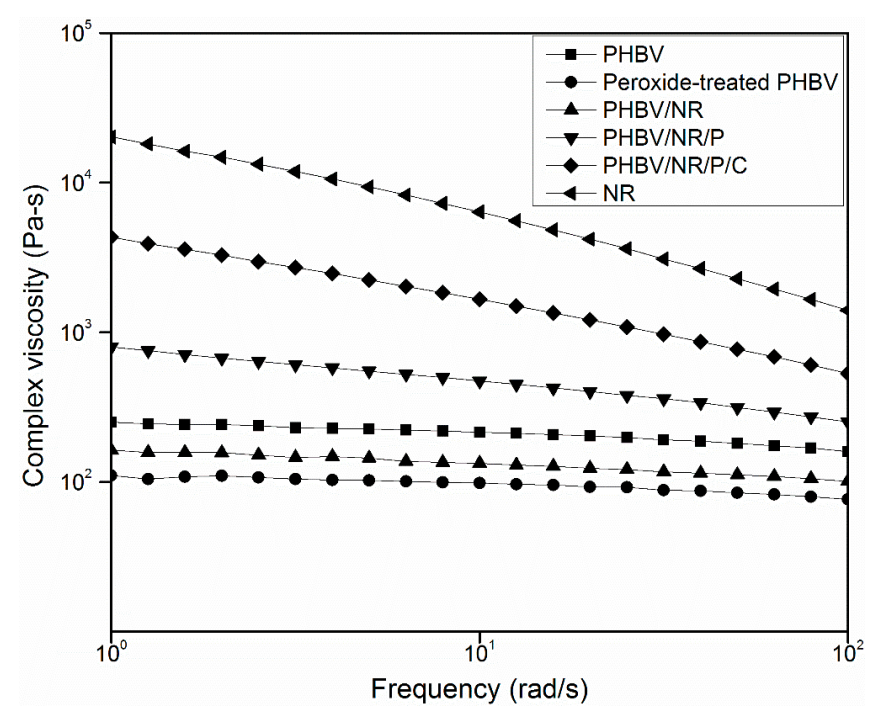

Figure 2. Complex viscosities of pristine PHBV, pristine NR, and PHBV/NR blends at $175^{\circ} \mathrm{C}$. 
The crosslinking effect of peroxide and coagent was further studied by way of van Gurp-Palmen plots (Figure 3), which depict the relationship between the complex modulus $\left(|G|^{*}\right)$ and phase angle $(\delta)$ of materials. These plots detect the fluid-solid transition of polymer melts [63], with high $\delta$ values indicating dominant liquid-like behavior and low $\delta$ values indicating the formation of a more elastic system [63,64]. Pristine PHBV, peroxide-treated PHBV, and PHBV/NR had phase angles of approximate $90^{\circ}$ at low $|G|^{*}$ values, reflecting their linear molecular chains with limited entanglements [65] and dominating fluid-like behavior. The observed high phase angle together with the previously discussed low complex viscosity of peroxide-treated PHBV indicated that a low peroxide content ( 3 phr) was insufficient to crosslink PHBV but was still able to degrade it. PHBV/NR/P had lower phase angles, indicating enhanced elastic behavior, likely caused by the formation of a partial rubber network reflected by its higher gel content than PHBV/NR. PHBV/NR/P/C had the lowest phase angle, similar to NR alone, indicating that coagent addition caused near-complete NR crosslinking, as demonstrated by its similar gel and rubber contents. The improved intraphase entanglements between NR and PHBV molecular chains were shown by FTIR and NMR analyses, discussed later. The rheological behavior of the $\mathrm{PHBV} / \mathrm{NR} / \mathrm{P} / \mathrm{C}$ blend is consistent with its improved mechanical properties, which will be discussed below.

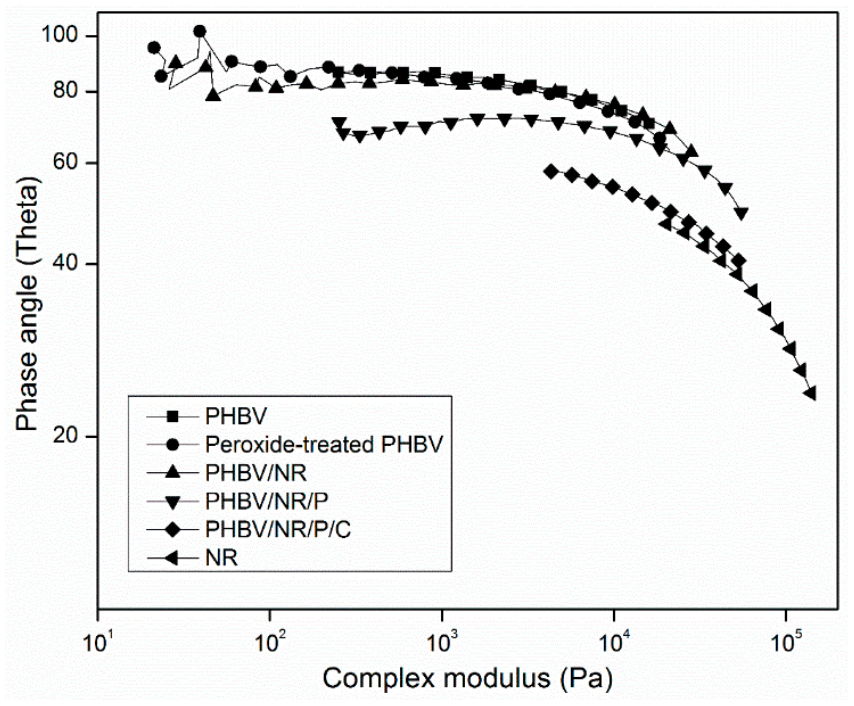

Figure 3. Van Gurp-Palmen plots of pristine PHBV, pristine NR, and PHBV/NR blends.

\subsection{Mechanical Properties}

Rubber addition decreased PHBV secant modulus, i.e., increased the flexibility, and increased tensile elongation (ductility) (Figure 4 ) by $40-100 \%$. This is mainly due to NR's liquid-like structural characteristic: the NR structure has no polar constituents. The van der Waals interactions between linear NR molecules cause coiled structures, leading to high flexibility and ductility $[66,67]$. The tensile strength of the blends was lower than that of pristine PHBV, mainly due to the low rubber modulus and strength ( 0.3 MPa and 0.25 MPa, respectively [68]). Similar results were observed in most of the NR-toughened systems, such as PLA/NR and PP/NR blends [69,70]. Although the blend strength can be improved by enhancing interfacial adhesion between the two phases [18], rubber-addition-caused strength loss of the plastic matrix seems unavoidable. PHBV/NR/P/C was stronger than PHBV/NR and $\mathrm{PHBV} / \mathrm{NR} / \mathrm{P}$, probably due to (1) coagent-induced rubber crosslinks and improved rubber modulus and strength, evinced by the high gel content and the high viscosity of PHBV/NR/P/C, respectively; and (2) increased intraphase entanglements between NR and PHBV, as discussed in the van Gurp-Palmen plots. Notched impact strength, i.e., toughness, was similar in PHBV, $\mathrm{PHBV} / \mathrm{NR}$, and $\mathrm{PHBV} / \mathrm{NR} / \mathrm{P}$, but was $75 \%$ higher in $\mathrm{PHBV} / \mathrm{NR} / \mathrm{C} / \mathrm{P}$. This is probably again due to coagent-induced improvement in rubber crosslinks and interfacial bonding between PHBV and 
rubber, which helps absorb more energy and allow more stress transfer between the two phases during the fracture process [71,72]. In contrast, peroxide alone improved the notched impact strength of PLA/NR (60/40) and PP/NR (85/15) blends $[53,70,73]$. This difference may be attributed to PHBV having a significantly lower thermal stability than PLA and PP, and it undergoes substantial chain scission, which can be enhanced by the presence of peroxide, during melt blending, as proved by gel permeation chromatography (GPC), NMR, and mass spectrometry [59-61].

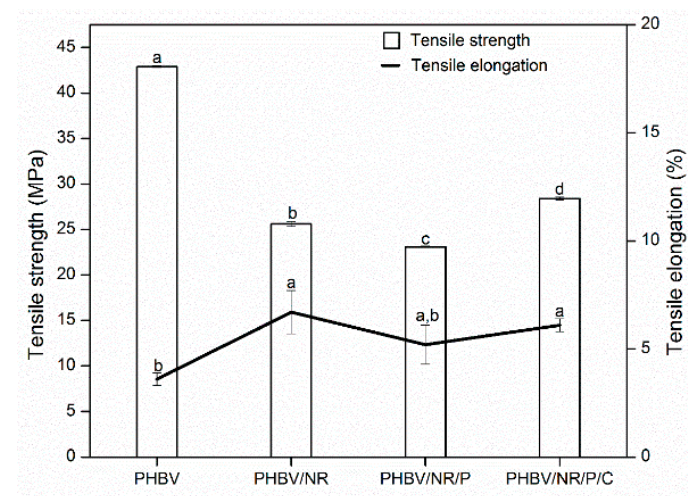

(a)

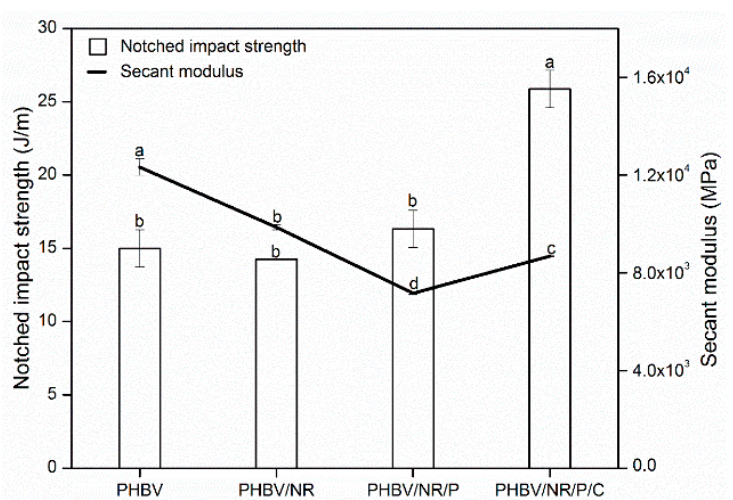

(b)

Figure 4. Mechanical properties of PHBV and the blends with NR. (Means showing different letters are significantly different at $\alpha=0.05$.)

To summarize, the PHBV/NR/P/C blend had a combination of mechanical properties, i.e., tensile elongation of $6 \%$, strength of $28 \mathrm{MPa}$, and notched impact strength (toughness) of $28 \mathrm{~J} \cdot \mathrm{m}^{-1}$, comparable to those of commercial thermoplastics such as general purpose polystyrene (tensile elongation of 3-9\% [74,75], tensile strength of 25-34 MPa [76,77], and notched impact strength of 16-21 J·m ${ }^{-1}$ [78]), suggesting it could be used as a bio-substitute for conventional plastics.

\subsection{Morphology}

The morphology of the different samples (Figure 5) was as predicted from their mechanical behavior. PHBV had a fairly smooth surface, which is typical of brittle materials [79], yet NR also displayed a smooth surface although it is a ductile polymer [80-82]. The observed smooth surfaces can be ascribed to the different fracturing mechanisms of the two polymers, i.e., the innately ductile rubber mainly fails through yielding while the inherently brittle PHBV fails through crazing [83-85]. The three blends had much rougher surfaces than pristine PHBV, indicating improved ductility [86] as supported by their increased tensile elongation. Although it is not possible to distinguish NR and PHBV in the blends from the images, the lack of the "pulling out" phenomenon on the cross sections of the blends suggested adhesion between the two phases [86,87]. PHBV/NR/P and PHBV/NR/P/C had rougher fracture surfaces than PHBV/NR, corresponding to their higher ductility, supported by their increased tensile elongation, increased viscosity, and improved elastic behavior (Figures 2 and 3). Such behavior is likely due to the peroxide and coagent enhancing interfacial adhesion between PHBV and NR. 

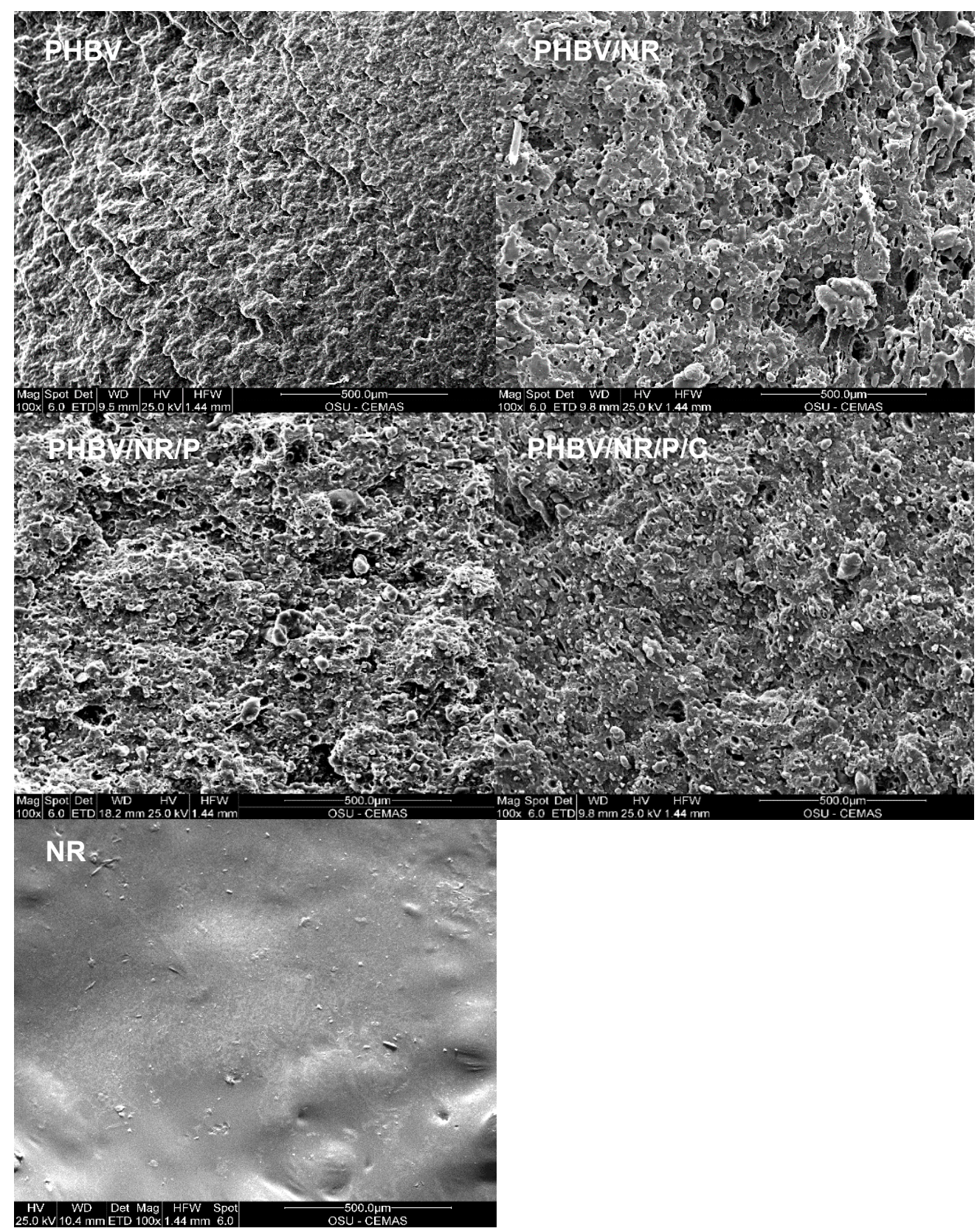

Figure 5. SEM images of the fracture surfaces of PHBV, NR, and the blends.

\subsection{Thermal Properties}

The three blends degraded in two stages (Figure 6), reflecting the different thermal stability of NR and PHBV. The first thermal degradation, between 285 and $310{ }^{\circ} \mathrm{C}$, was associated with PHBV degradation, while the second stage, between 310 and $450{ }^{\circ} \mathrm{C}$, was related to NR degradation [38]. The gels from PHBV/NR/P and PHBV/NR/P/C blends had TGA thermograms similar to that of NR, indicating that the gels from the two blends mainly contained rubber, while the slight decomposition around $300{ }^{\circ} \mathrm{C}$ may be associated with grafted PHBV. The similar onset thermal degradation temperatures $\left(T_{\mathrm{o}}\right)$ of pristine PHBV and the PHBV phase in the blends indicate that some of the PHBV was not grafted to NR. However, grafted PHBV/NR was clearly observed due to its intermediate peak degradation temperatures ( $T_{p}$, Table 4$)$. The presence of NR (both grafted and ungrafted) limited PHBV degradation during heating and rotational stresses of extrusion due to rubber dissipating heat more efficiently than PHBV. $T_{\mathrm{p}}-T_{\mathrm{m}}$ of PHBV increased from $127^{\circ} \mathrm{C}$ to 142,138 , and 
$139^{\circ} \mathrm{C}$ in PHBV/NR, PHBV/NR/P, and PHBV/NR/P/C (Table 4), respectively, expanding the range of PHBV processing temperatures and broadening the processing window $[9,88]$.

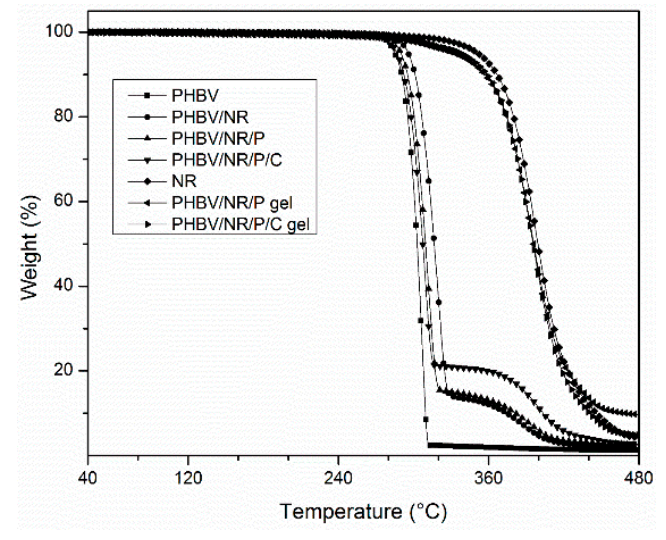

(a)

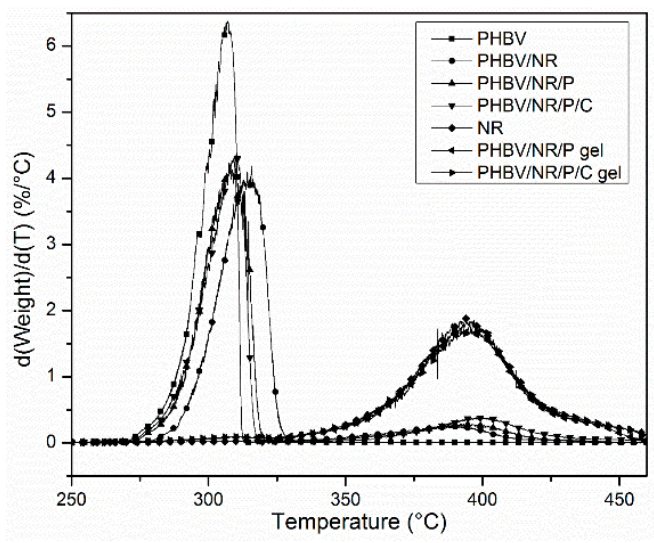

(b)

Figure 6. (a) Weight loss TGA thermograms; (b) Derivative weight loss TGA thermograms of pristine PHBV, pristine NR, blends of PHBV and NR, and the gels from PHBV/NR/P and PHBV/NR/P/C.

Table 4. Melting, crystallization, glass transition, peak thermal degradation temperatures and degree of crystallinity of PHBV and NR and the blends determined from 2nd heating and 1st cooling of DSC at $10{ }^{\circ} \mathrm{C} \mathrm{min}-1$, respectively.

\begin{tabular}{ccccccc}
\hline Sample & $\boldsymbol{T}_{\mathbf{m}}\left({ }^{\circ} \mathbf{C}\right)$ & $\boldsymbol{T}_{\mathbf{c}(\text { peak) }}\left({ }^{\circ} \mathbf{C}\right)$ & $\boldsymbol{T}_{\mathbf{g}(\mathbf{N R})}\left({ }^{\circ} \mathbf{C}\right)$ & $\boldsymbol{T}_{\mathbf{g}(\mathbf{P H B V})}\left({ }^{\circ} \mathbf{C}\right)$ & $\boldsymbol{T}_{\mathbf{p}}\left({ }^{\circ} \mathbf{C}\right)$ & $\boldsymbol{X}_{\mathbf{c}}(\mathbf{\%})$ \\
\hline PHBV & $172.0 \pm 0.04$ & $120.8 \pm 0.17$ & - & $5.6 \pm 0.30$ & $299.4 \pm 0.93$ & $74.7 \pm 0.02$ \\
PHBV $/ N R$ & $171.9 \pm 0.56$ & $119.4 \pm 0.59$ & $-64.5 \pm 0.52$ & $6.0 \pm 0.30$ & $313.7 \pm 1.49$ & $61.6 \pm 0.02$ \\
$\mathrm{PHBV} / \mathrm{NR} / \mathrm{P}$ & $171.7 \pm 0.26$ & $117.2 \pm 0.30$ & $-65.2 \pm 0.41$ & $6.2 \pm 0.30$ & $309.5 \pm 2.74$ & $58.8 \pm 0.02$ \\
$\mathrm{PHBV} / \mathrm{NR} / \mathrm{P} / \mathrm{C}$ & $169.8 \pm 0.54$ & $116.8 \pm 0.33$ & $-65.8 \pm 0.54$ & $4.3 \pm 0.30$ & $308.7 \pm 1.63$ & $56.8 \pm 0.02$ \\
NR & - & - & $-66.8 \pm 0.08$ & - & $394.7 \pm 1.16$ & - \\
\hline
\end{tabular}

The column headings are $T_{\mathrm{m}}$, melting temperature; $T_{\mathrm{c}(\text { peak })}$, peak crystallization temperature; $T_{\mathrm{g}(\mathrm{NR})}$, glass transition temperature corresponding to NR component; $T_{\mathrm{g}(\mathrm{PHBV})}$, glass transition temperature corresponding to PHBV component; $T_{\mathrm{p}}$, peak thermal degradation temperature; and $X_{\mathrm{c}}$, degree of crystallinity.

\subsection{Crystallization Properties}

\subsubsection{DSC}

The three blends had two glass transition temperatures $\left(T_{\mathrm{g}}\right)$ which corresponded to the $T_{\mathrm{g}}$ values of NR $\left(-67^{\circ} \mathrm{C}\right)$ and PHBV $\left(5^{\circ} \mathrm{C}\right)$, respectively (Table 4$)$. The polymer melt temperature $\left(T_{\mathrm{m}}\right)$ and degree of crystallinity $\left(X_{\mathrm{c}}\right)$ decreased with increasing blend complexity. These changes, together with the slightly decreased crystallization temperatures of PHBV in the three blends, are consistent with the formation of imperfect crystallites, as observed previously in PHBV/nitrile blends [52,89]. These changes were likely due to two reasons: (1) the peroxide and coagent induced the formation of polymer networks, restricting PHBV crystallization, and (2) rubber particles migrating into the inter- and intra-spherulitic regions of crystalline PHBV, retarding crystal growth. Similar results were found in PP/EPDM/NR blends, where peroxide increased polymer chain crosslinks, particle size, and viscosity and interrupted the ability of PP molecules to align, further lowering the melt temperature and crystallinity [90]. All blends in this study were more flexible and less crystalline than pristine PHBV, but only PHBV/NR/P/C was tougher, even though both flexibility and toughness result from reduced crystallinity in brittle polymers [91,92].

\subsubsection{XRD}

When the crystallization behavior of PHBV, alone and in the blends, was investigated by XRD, similar diffraction peaks [(020), (110), and (121)] indicating highly crystalline structures were observed 
(Figure 7a). However, the intensity of peaks (121) and, therefore, the degree of crystallinity dramatically decreased in the blends, confirming the DSC observations. No new peaks were observed in the XRD patterns of the blends, indicating that no new crystalline phases formed [93]. The (020), (110), and (121) peaks of PHBV shifted to higher angles in the blends, indicating decreased d-spacing (distance between atomic layers in a crystal), which was probably caused by lattice parameter changes [94], such as the formation of thinner crystals. PHBV $/ \mathrm{NR} / \mathrm{P} / \mathrm{C}$ had the smallest $\mathrm{d}$-spacing among the three blends, since increased crosslinks caused the greatest inhibition of crystal growth. PHBV crystal size, which was not related to the d-spacing but was inversely proportional to the FWHM of the peak [46-48], decreased from 25.5 to $23.5 \mathrm{~nm}$ in $\mathrm{PHBV} / \mathrm{NR} / \mathrm{P} / \mathrm{C}$ while it was unchanged in the other blends. The small crystals may contribute to improved $\mathrm{PHBV} / \mathrm{NR} / \mathrm{P} / \mathrm{C}$ toughness because they can reduce stress concentration. Highly concentrated stress is not desirable as it induces premature fracture, which increases the size of crystalline/amorphous phase interfaces and causes crack propagation $[95,96]$. Thus, small crystals improve toughness because they can enhance stress propagation and facilitate shear yielding of the plastic matrix $[97,98]$.

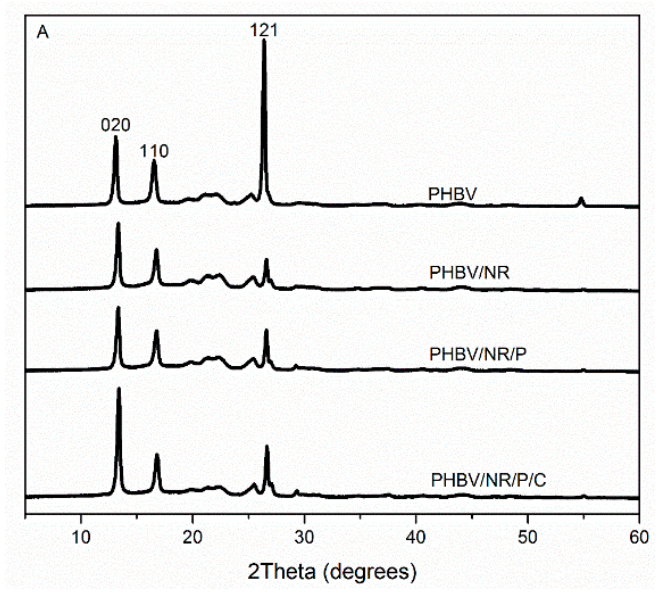

(a)

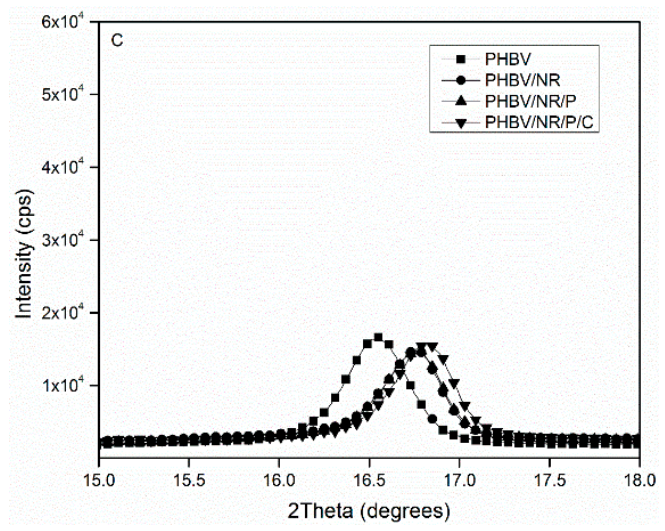

(c)

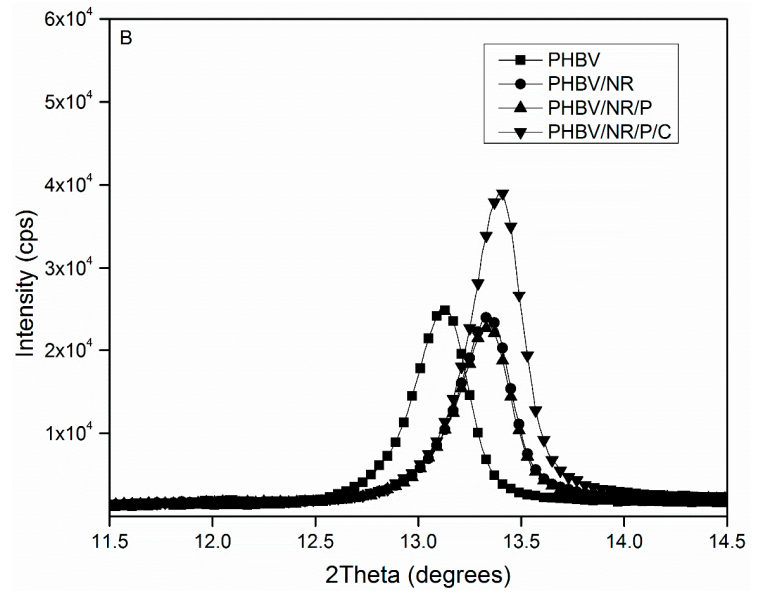

(b)

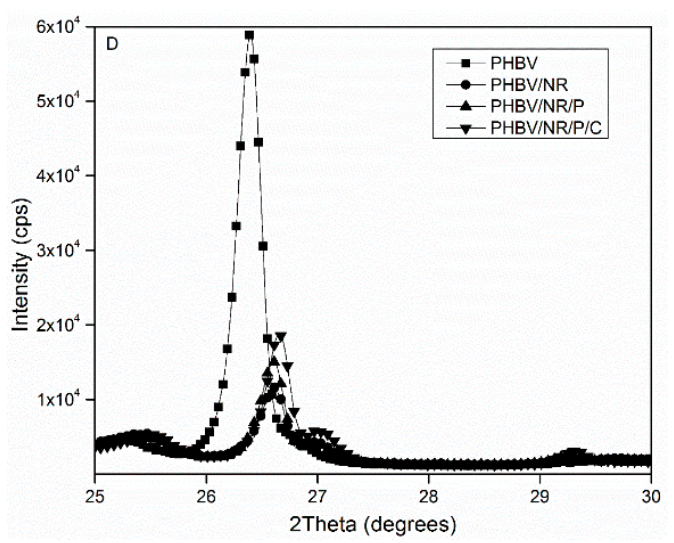

(d)

Figure 7. XRD patterns of pristine PHBV and the blends. (a) Overall XRD pattern from $2 \theta=5^{\circ}$ to $2 \theta=60^{\circ}$; (b) XRD pattern of diffraction peak (020); (c) XRD pattern of diffraction peak (110); (d) XRD pattern of diffraction peak (121).

\subsection{Reaction Mechanism}

The gel and soluble fractions from chloroform extraction of the blends were characterized through FTIR and NMR, respectively, to investigate the reaction mechanism(s) of the coagent-assisted peroxide-induced reactive blending of PHBV and NR (Figure 8). The FTIR spectra of the gels 
were almost identical to those of pristine NR (Figure 9), indicating complete removal of free PHBV components during chloroform extraction of the blends.

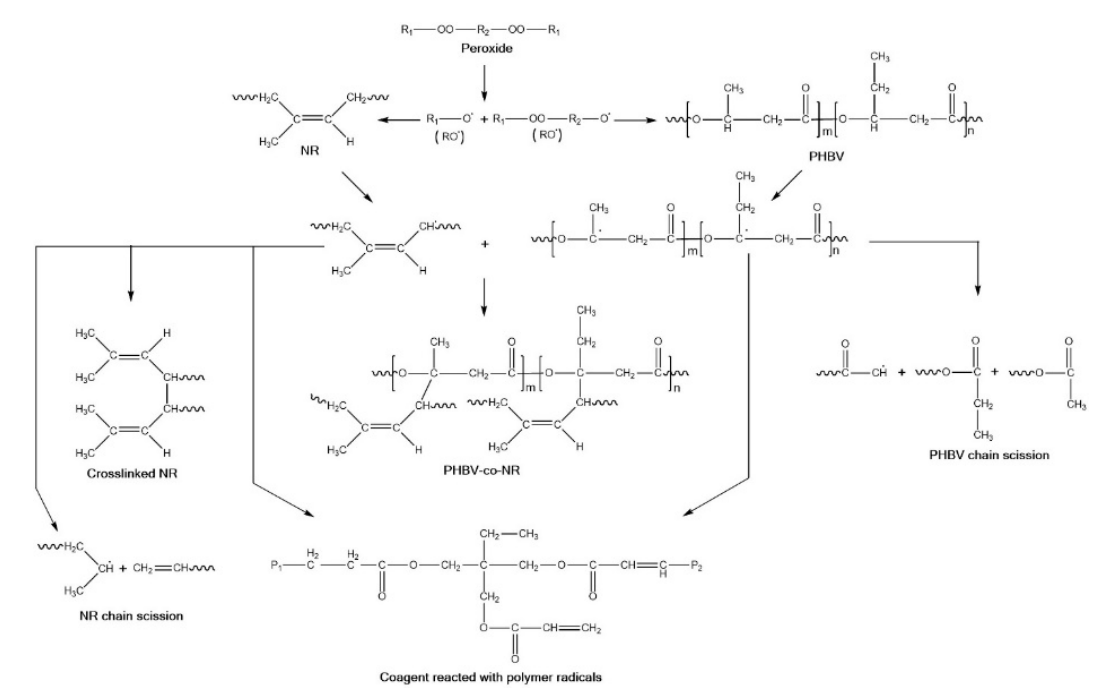

Figure 8. Possible reactions during melt blending of PHBV and NR in the presence of peroxide and coagent.

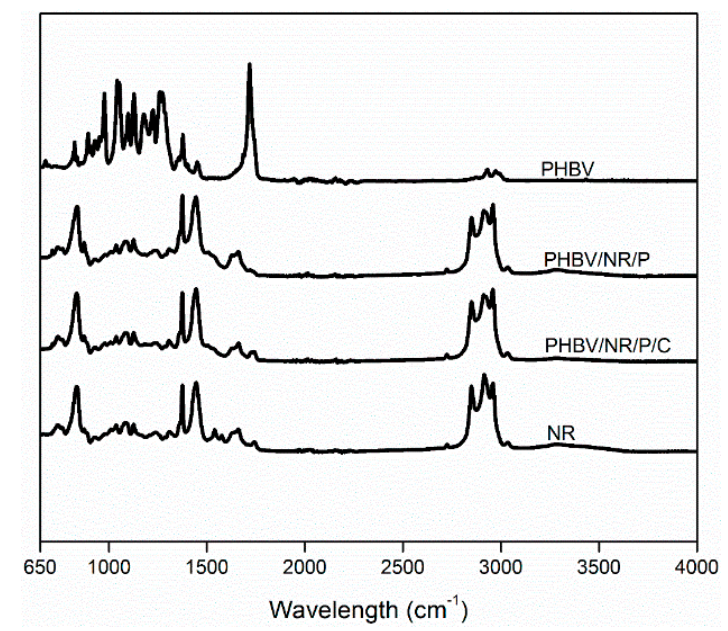

Figure 9. FTIR spectra of pristine PHBV, pristine NR, and gels from $\mathrm{PHBV} / \mathrm{NR} / \mathrm{P}$ and $\mathrm{PHBV} / \mathrm{NR} / \mathrm{P} / \mathrm{C}$ blends obtained through chloroform extraction.

\subsubsection{FTIR}

Peaks at $1662 \mathrm{~cm}^{-1}$ (representing $\mathrm{C}=\mathrm{C}$ bonds) were visible in NR and the gels from the blends (Figure 9). These may reflect unreacted NR double bonds and/or that rubber crosslinking occurring at the active $\alpha-\mathrm{H}$ adjacent to the double bonds [99] (Figure 8). Peaks at $2957 \mathrm{~cm}^{-1}$ (representing $\mathrm{C}-\mathrm{H}$ asymmetric stretch in $\mathrm{CH}_{3}$ groups) [100] were more intense in the gels from $\mathrm{PHBV} / \mathrm{NR} / \mathrm{P}$ and $\mathrm{PHBV} / \mathrm{NR} / \mathrm{P} / \mathrm{C}$ than in NR, indicating grafting of PHBV and/or coagent onto NR backbones [101]. Peaks at $1539 \mathrm{~cm}^{-1}$ and $1576 \mathrm{~cm}^{-1}$, both representing $\mathrm{N}-\mathrm{H}$ stretch, $\mathrm{C}=\mathrm{O}$, and $\mathrm{N}-\mathrm{H}$ bending of amide groups of rubber proteins [102], were weakened in the blends, which may reflect protein degradation during the melt blending process. FTIR analysis indicated degradation of a particular fraction of the rubber proteins, for example, water-soluble and membrane-associated proteins [103]. The water-soluble proteins are the main immunogens in latex allergy [103]. 


\subsubsection{NMR}

${ }^{1} \mathrm{H}$ NMR spectra of the chloroform-soluble fractions of $\mathrm{PHBV} / \mathrm{NR} / \mathrm{P}$ and $\mathrm{PHBV} / \mathrm{NR} / \mathrm{P} / \mathrm{C}$ were similar to that of pristine PHBV (Figure 10), indicating that the soluble fractions mainly contained PHBV. Peaks at 2.02 and $1.65 \mathrm{ppm}$, belonging to the characteristic hydrogen protons of NR, were visible in PHBV/NR/P and PHBV/NR/P/C spectra, suggesting the formation of soluble PHBV-grafted-NR copolymers during the melt blending process. The peak at $1.56 \mathrm{ppm}$ in the $\mathrm{PHBV} / \mathrm{NR} / \mathrm{P} / \mathrm{C}$ sol spectrum may be caused by the water in the samples. No peaks belonging to the coagent were observed, indicating that most of the coagent units were in the blend gels.

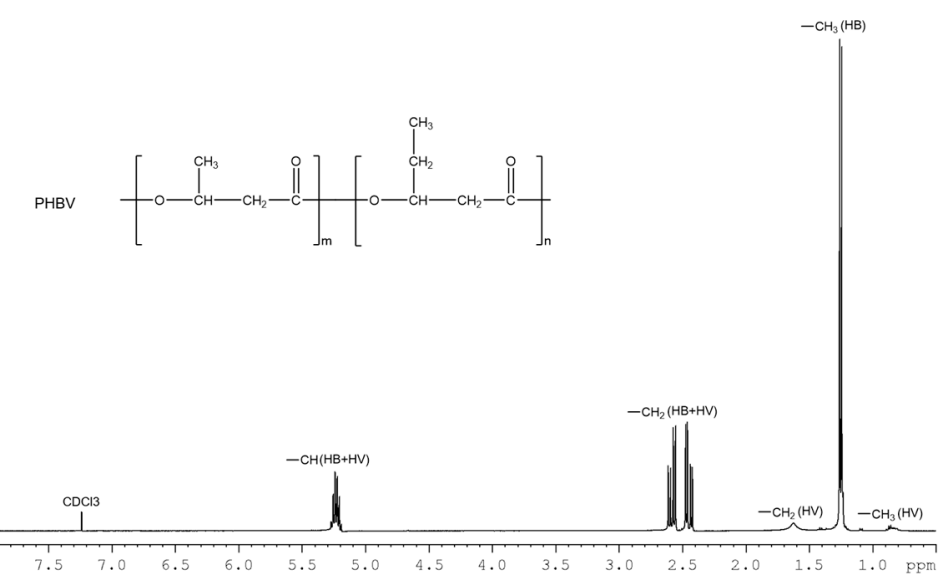

(a)

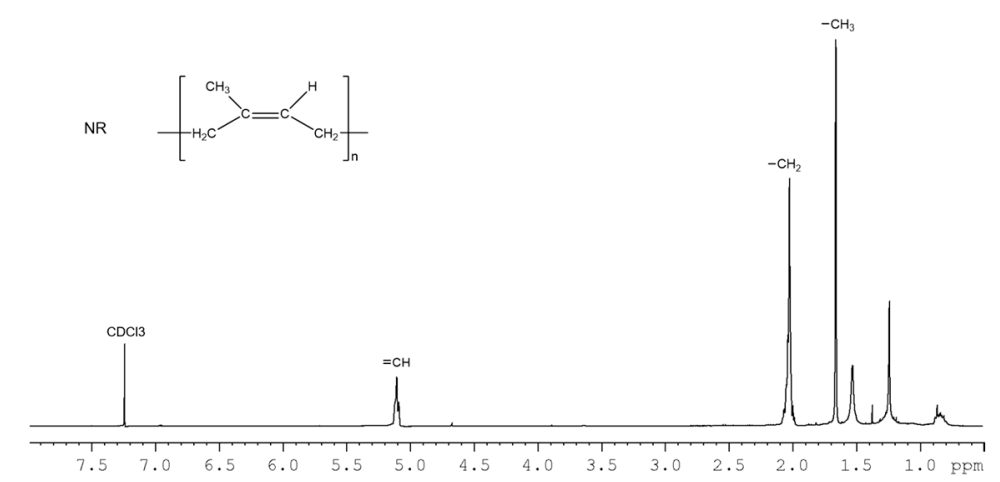

(b)

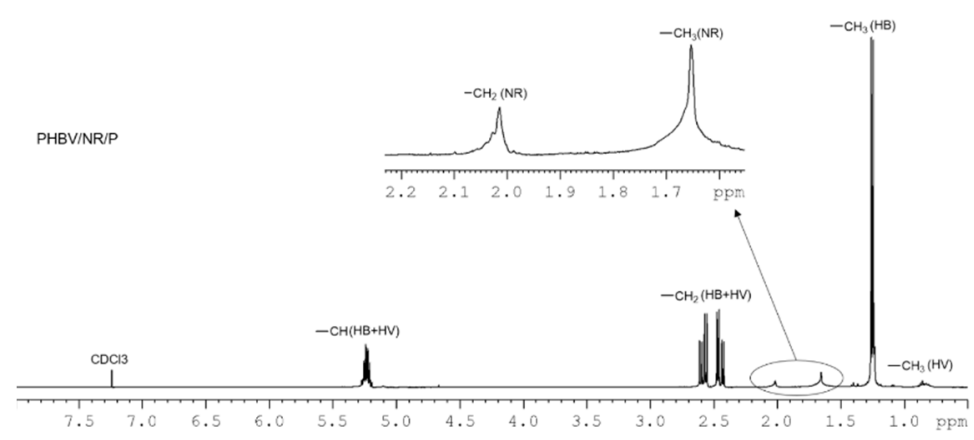

(c)

Figure 10. Cont. 


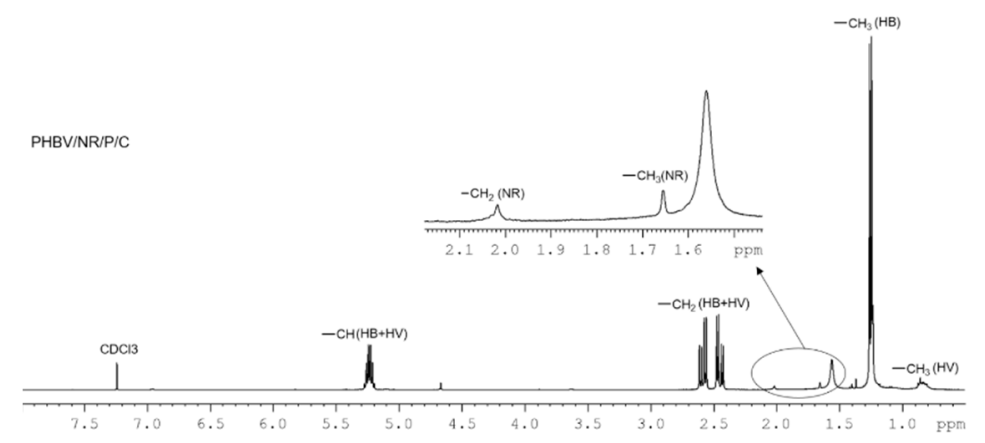

(d)

Figure 10. ${ }^{1} \mathrm{H}$ NMR spectra of (a) PHBV, (b) NR, (c) the chloroform-soluble part of PHBV/NR/P, and (d) the chloroform-soluble part of $\mathrm{PHBV} / \mathrm{NR} / \mathrm{P} / \mathrm{C}$.

Thus, peroxide and coagent crosslinked the rubber phase in the blends. Grafting between PHBV and NR occurred during the melt blending process, forming two types of PHBV-grafted-NR structures (PHBV-co-NR, Figure 8): one locked within the rubber gel (indicated by the TGA analysis, Figure 5, and FTIR analysis, Figure 9) and one soluble in chloroform (indicated by the NMR analysis of the blend sols, Figure 10). Coagent bridges between two polymer chains formed and behaved similarly to reinforcing fillers in PHBV/NR blends (Figure 11) $[37,65]$, improving matrix strength.

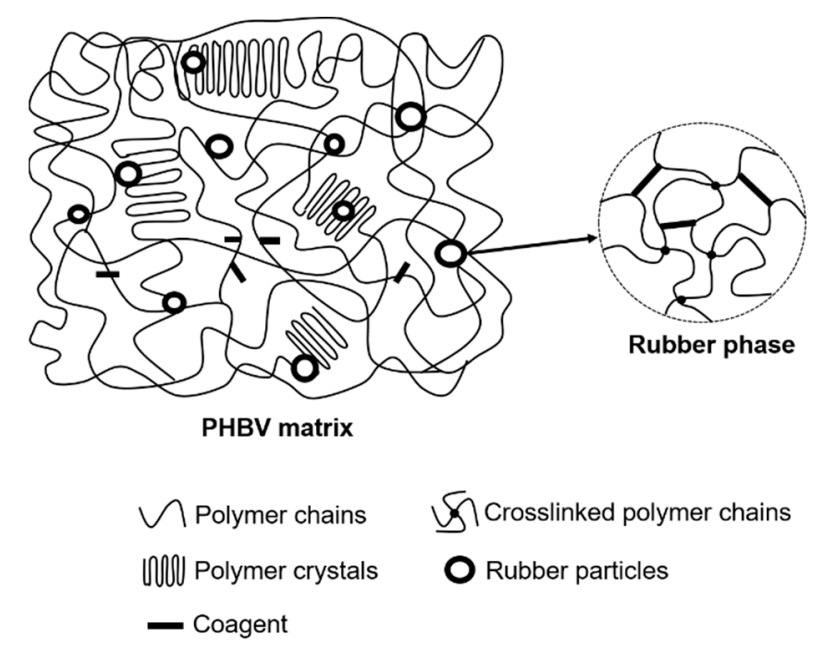

Figure 11. A conceptual structure of a coagent-assisted peroxide-cured PHBV/NR blend.

\section{Conclusions}

The rubber toughening efficiency of reactively extruded PHBV/NR blends was significantly improved through the synergistic use of coagent and peroxide, which crosslinked NR and grafted PHBV onto NR, resulting in increased interfacial adhesion, NR modulus, and cohesive strength while suppressing peroxide-induced thermal degradation of PHBV and decreasing PHBV crystallization. The new PHBV/NR blend had significantly improved toughness (by $\sim 75 \%$ ) and ductility (by $\sim 100 \%)$ with minimal strength loss $(\sim 30 \%)$. This enhanced mechanical performance was much improved from that of other conventional dynamically vulcanized PHBV/NR blends, where rubber addition significantly decreased PHBV strength (by $40-80 \%$ ) with only slight to moderate toughness improvement (by 10-50\%) [35,38,104,105]. The new PHBV/NR material has mechanical properties (strength of $28 \mathrm{MPa}$ and toughness of $28 \mathrm{~J} \mathrm{~m}^{-1}$ ) and processing windows comparable to those of some commercial plastics, such as PP and HDPE, and can replace some petroleum-based conventional thermoplastics in cast sheets and thermoforms, including those used in food packaging. Our insights 
into the reaction and toughening mechanisms of rubber-toughened PHBV lay the groundwork for future performance improvements.

Author Contributions: Conceptualization, Y.V., K.C., and X.Z.; methodology, X.Z.; formal analysis, X.Z.; data curation, X.Z.; writing-original draft preparation, X.Z.; writing-review and editing, Y.V. and K.C.; supervision, Y.V. and K.C.; funding acquisition, Y.V. and K.C.

Funding: This research was funded by Center for Advanced Processing and Packaging Studies (CAPPS), grant number 60040668 .

Acknowledgments: The authors would like to thank Jose Castro for supplying the Instron UTM instrument and impact tester used in this study, and the Polymer Center (Charlotte, NC) for assisting with the injection molding of the mechanical testing specimens.

Conflicts of Interest: The authors declare no conflict of interest.

\section{References}

1. Alavi, S.; Thomas, S.; Sandeep, K.; Kalarikkal, N.; Varghese, J.; Yaragalla, S. Polymers for Packaging Applications; CRC Press: Boca Raton, FL, USA, 2014.

2. Jendrossek, D.; Schirmer, A.; Schlegel, H. Biodegradation of polyhydroxyalkanoic acids. Appl. Microbiol. Biotechnol. 1996, 46, 451-463. [CrossRef]

3. Zinn, M.; Witholt, B.; Egli, T. Occurrence, synthesis and medical application of bacterial polyhydroxyalkanoate. Adv. Drug Deliv. Rev. 2001, 53, 5-21. [CrossRef]

4. Poli, A.; Di Donato, P.; Abbamondi, G.R.; Nicolaus, B. Synthesis, production, and biotechnological applications of exopolysaccharides and polyhydroxyalkanoates by archaea. Archaea 2011, 2011, 693253. [CrossRef] [PubMed]

5. Biron, M. Industrial Applications of Renewable Plastics: Environmental, Technological, and Economic Advances; William Andrew: New York, NY, USA, 2016.

6. Roy, I.; Visakh, P. Polyhydroxyalkanoate (PHA) Based Blends, Composites and Nanocomposites; Royal Society of Chemistry: New York, NY, USA, 2014; Volume 30.

7. Yu, H.; Yan, C.; Yao, J. Fully biodegradable food packaging materials based on functionalized cellulose nanocrystals/poly (3-hydroxybutyrate-co-3-hydroxyvalerate) nanocomposites. RSC Adv. 2014, 4, 59792-59802. [CrossRef]

8. Modi, S.; Koelling, K.; Vodovotz, Y. Assessment of PHB with varying hydroxyvalerate content for potential packaging applications. Eur. Polym. J. 2011, 47, 179-186. [CrossRef]

9. Wang, S.; Song, C.; Chen, G.; Guo, T.; Liu, J.; Zhang, B.; Takeuchi, S. Characteristics and biodegradation properties of poly (3-hydroxybutyrate-co-3-hydroxyvalerate)/organophilic montmorillonite (PHBV/OMMT) nanocomposite. Polym. Degrad. Stab. 2005, 87, 69-76. [CrossRef]

10. Pilla, S. Handbook of Bioplastics and Biocomposites Engineering Applications; John Wiley \& Sons: New York, NY, USA, 2011; Volume 81.

11. Li, J.; Lai, M.; Liu, J. Effect of poly (propylene carbonate) on the crystallization and melting behavior of poly ( $\beta$-hydroxybutyrate-co- $\beta$-hydroxyvalerate). J. Appl. Polym. Sci. 2004, 92, 2514-2521. [CrossRef]

12. Choi, J.S.; Park, W.H. Effect of biodegradable plasticizers on thermal and mechanical properties of poly (3-hydroxybutyrate). Polym. Test. 2004, 23, 455-460. [CrossRef]

13. Qian, J.; Zhu, L.; Zhang, J.; Whitehouse, R.S. Comparison of different nucleating agents on crystallization of poly (3-hydroxybutyrate-co-3-hydroxyvalerates). J. Polym. Sci. Part B Polym. Phys. 2007, 45, 1564-1577. [CrossRef]

14. Yu, H.-y.; Qin, Z.-y.; Zhe, Z. Cellulose nanocrystals as green fillers to improve crystallization and hydrophilic property of poly (3-hydroxybutyrate-co-3-hydroxyvalerate). Prog. Nat. Sci. Mater. Int. 2011, 21, 478-484. [CrossRef]

15. Avella, M.; Martuscelli, E.; Raimo, M. Review Properties of blends and composites based on poly (3-hydroxy) butyrate (PHB) and poly (3-hydroxybutyrate-hydroxyvalerate)(PHBV) copolymers. J. Mater. Sci. 2000, 35, 523-545. [CrossRef]

16. Baillie, C.; Jayasinghe, R. Green composites: Towards a sustainable future? In Green Composites, 2nd ed.; Elsevier: New York, NY, USA, 2017; pp. 1-5. 
17. Walker, I.; Collyer, A. Rubber toughening mechanisms in polymeric materials. In Rubber Toughened Engineering Plastics; Springer: New York, NY, USA, 1994; pp. 29-56.

18. Liang, J.; Li, R. Rubber toughening in polypropylene: A review. J. Appl. Polym. Sci. 2000, 77, 409-417. [CrossRef]

19. Bucknall, C.; Karpodinis, A.; Zhang, X. A model for particle cavitation in rubber-toughened plastics. J. Mater. Sci. 1994, 29, 3377-3383. [CrossRef]

20. Muratoglu, O.; Argon, A.; Cohen, R.; Weinberg, M. Toughening mechanism of rubber-modified polyamides. Polymer 1995, 36, 921-930. [CrossRef]

21. Van Dommelen, J.; Brekelmans, W.; Baaijens, F. Micromechanical modeling of particle-toughening of polymers by locally induced anisotropy. Mech. Mater. 2003, 35, 845-863. [CrossRef]

22. Bartczak, Z.; Argon, A.S.; Cohen, R.E.; Weinberg, M. Toughness mechanism in semi-crystalline polymer blends: II. High-density polyethylene toughened with calcium carbonate filler particles. Polymer 1999, 40, 2347-2365. [CrossRef]

23. Zhang, B.; Bian, X.; Xiang, S.; Li, G.; Chen, X. Synthesis of PLLA-based block copolymers for improving melt strength and toughness of PLLA by in situ reactive blending. Polym. Degrad. Stab. 2017, 136, 58-70. [CrossRef]

24. Zhang, N.; Lu, X. Morphology and properties of super-toughened bio-based poly (lactic acid)/poly (ethylene-co-vinyl acetate) blends by peroxide-induced dynamic vulcanization and interfacial compatibilization. Polym. Test. 2016, 56, 354-363. [CrossRef]

25. Zeng, J.-B.; Li, K.-A.; Du, A.-K. Compatibilization strategies in poly (lactic acid)-based blends. RSC Adv. 2015, 5, 32546-32565. [CrossRef]

26. Shonaike, G.O.; Simon, G.P. Polymer Blends and Alloys; CRC Press: New York, NY, USA, 1999; Volume 52.

27. Zhang, Z.; Zhao, X.; Wang, S.; Zhang, J.; Zhang, W. Inducing a network structure of rubber phase: An effective approach to toughen polymer without sacrificing stiffness. RSC Adv. 2014, 4, 60617-60625. [CrossRef]

28. Chen, Y.; Yuan, D.; Xu, C. Dynamically vulcanized biobased polylactide/natural rubber blend material with continuous cross-linked rubber phase. ACS Appl. Mater. Interfaces 2014, 6, 3811-3816. [CrossRef] [PubMed]

29. Babu, R.R.; Singha, N.K.; Naskar, K. Dynamically vulcanized blends of polypropylene and ethylene octene copolymer: Influence of various coagents on thermal and rheological characteristics. J. Appl. Polym. Sci. 2010, 117, 1578-1590. [CrossRef]

30. Luo, S.; Cao, J.; McDonald, A.G. Interfacial improvements in a green biopolymer alloy of poly (3-hydroxybutyrate-co-3-hydroxyvalerate) and lignin via in situ reactive extrusion. ACS Sustain. Chem. Eng. 2016, 4, 3465-3476. [CrossRef]

31. Ma, P.; Hristova-Bogaerds, D.G.; Lemstra, P.J.; Zhang, Y.; Wang, S. Toughening of PHBV/PBS and $\mathrm{PHB} / \mathrm{PBS}$ Blends via In situ Compatibilization Using Dicumyl Peroxide as a Free-Radical Grafting Initiator. Macromol. Mater. Eng. 2012, 297, 402-410. [CrossRef]

32. Henning, S.K.; Costin, R. Fundamentals of Curing Elastomers with Peroxides and Coagents I: Coagent Structure-Property Relationships. In Proceedings of the 167th Technical Meeting of the Rubber Division, San Antonio, TX, USA, 16-18 May 2005; American Chemical Society: Washington, DC, USA, 2005; pp. $16-18$.

33. Wan, C. Reactive Modification of Polyesters and Their Blends; ProQuest: Ann Arbor, MI, USA, 2004.

34. Zhao, X. Toughen PHBV Bioplastics with Natural Rubber to Broaden Their Packaging Applications. Ph.D. Dissertation, The Ohio State University, Columbus, OH, USA, 2018.

35. Zhao, X.; Venoor, V.; Koelling, K.; Cornish, K.; Vodovotz, Y. Bio-based blends from poly(3-hydroxybutyrate-co3-hydroxyvalerate) and natural rubber for packaging applications. J. Appl. Polym. Sci. 2018, 47334. [CrossRef]

36. Do, I.; Yoon, L.; Kim, B.; Jeong, H. Effect of viscosity ratio and peroxide/coagent treatment in PP/EPR/PE ternary blends. Eur. Polym. J. 1996, 32, 1387-1393. [CrossRef]

37. Babu, R.R.; Singha, N.K.; Naskar, K. Dynamically vulcanized blends of polypropylene and ethylene octene copolymer: Influence of various coagents on mechanical and morphological characteristics. J. Appl. Polym. Sci. 2009, 113, 3207-3221. [CrossRef]

38. Modi, S.J.; Cornish, K.; Koelling, K.; Vodovotz, Y. Fabrication and improved performance of poly (3-hydroxybutyrate-co-3-hydroxyvalerate) for packaging by addition of high molecular weight natural rubber. J. Appl. Polym. Sci. 2016, 133. [CrossRef] 
39. Modi, S.; Koelling, K.; Vodovotz, Y. Assessing the mechanical, phase inversion, and rheological properties of poly-[(R)-3-hydroxybutyrate-co-(R)-3-hydroxyvalerate](PHBV) blended with poly-(l-lactic acid)(PLA). Eur. Polym. J. 2013, 49, 3681-3690. [CrossRef]

40. Modi, S.; Koelling, K.; Vodovotz, Y. Miscibility of poly (3-hydroxybutyrate-co-3-hydroxyvalerate) with high molecular weight poly (lactic acid) blends determined by thermal analysis. J. Appl. Polym. Sci. 2012, 124, 3074-3081. [CrossRef]

41. Kuntanoo, K.; Promkotra, S.; Kaewkannetra, P. Biodegradation of polyhydroxybutyrate-co-hydroxyvalerate (PHBV) blended with natural rubber in soil environment. Int. Sci. Index. 2013, 7, 12.

42. McNally, T.; McShane, P.; Nally, G.; Murphy, W.; Cook, M.; Miller, A. Rheology, phase morphology, mechanical, impact and thermal properties of polypropylene/metallocene catalysed ethylene 1-octene copolymer blends. Polymer 2002, 43, 3785-3793. [CrossRef]

43. Yin, B.; Zhao, Y.; Yang, W.; Pan, M.-m.; Yang, M.-b. Polycarbonate/liquid crystalline polymer blend: Crystallization of polycarbonate. Polymer 2006, 47, 8237-8240. [CrossRef]

44. Buonerba, A.; Cuomo, C.; Speranza, V.; Grassi, A. Crystalline syndiotactic polystyrene as reinforcing agent of cis-1, 4-polybutadiene rubber. Macromolecules 2009, 43, 367-374. [CrossRef]

45. Carli, L.N.; Daitx, T.S.; Soares, G.V.; Crespo, J.S.; Mauler, R.S. The effects of silane coupling agents on the properties of PHBV/halloysite nanocomposites. Appl. Clay Sci. 2014, 87, 311-319. [CrossRef]

46. Yei, D.-R.; Kuo, S.-W.; Su, Y.-C.; Chang, F.-C. Enhanced thermal properties of PS nanocomposites formed from inorganic POSS-treated montmorillonite. Polymer 2004, 45, 2633-2640. [CrossRef]

47. Thayer, T.A.; Bagby, M.D.; Moore, R.N.; DeAngelis, R.J. X-ray diffraction of nitinol orthodontic arch wires. Am. J. Orthod. Dentofac. Orthop. 1995, 107, 604-612. [CrossRef]

48. Uvarov, V.; Popov, I. Metrological characterization of X-ray diffraction methods at different acquisition geometries for determination of crystallite size in nano-scale materials. Mater. Charact. 2013, 85, 111-123. [CrossRef]

49. Li, S.D.; Yu, H.P.; Peng, Z.; Zhu, C.S.; Li, P.S. Study on thermal degradation of sol and gel of natural rubber. J. Appl. Polym. Sci. 2000, 75, 1339-1344. [CrossRef]

50. Moad, G. The synthesis of polyolefin graft copolymers by reactive extrusion. Prog. Polym. Sci. 1999, 24, 81-142. [CrossRef]

51. Immirzi, B.; Malinconico, M.; Orsello, G.; Portofino, S.; Volpe, M. Blends of biodegradable polyesters by reactive blending: Preparation, characterisation and properties. J. Mater. Sci. 1999, 34, 1625-1639. [CrossRef]

52. Thitithammawong, A.; Nakason, C.; Sahakaro, K.; Noordermeer, J. Effect of different types of peroxides on rheological, mechanical, and morphological properties of thermoplastic vulcanizates based on natural rubber/polypropylene blends. Polym. Test. 2007, 26, 537-546. [CrossRef]

53. Bhowmick, A.K.; Stephens, H. Handbook of Elastomers; CRC Press: Boca Raton, FL, USA, 2000.

54. Utara, S.; Boochathum, P. Novel dynamic vulcanization of polyethylene and ozonolysed natural rubber blends: Effect of curing system and blending ratio. J. Appl. Polym. Sci. 2011, 120, 2606-2614. [CrossRef]

55. Yan, D.; Wang, W.-J.; Zhu, S. Effect of long chain branching on rheological properties of metallocene polyethylene. Polymer 1999, 40, 1737-1744. [CrossRef]

56. Dluzneski, P.R. Peroxide vulcanization of elastomers. Rubber Chem. Technol. 2001, 74, 451-492. [CrossRef]

57. Wei, L.; McDonald, A.G. Accelerated weathering studies on the bioplastic, poly(3-hydroxybutyrate-co3-hydroxyvalerate). Polym. Degrad. Stab. 2016, 126, 93-100. [CrossRef]

58. D'Haene, P.; Remsen, E.E.; Asrar, J. Preparation and characterization of a branched bacterial polyester. Macromolecules 1999, 32, 5229-5235. [CrossRef]

59. Liu, Q.-S.; Zhu, M.-F.; Wu, W.-H.; Qin, Z.-Y. Reducing the formation of six-membered ring ester during thermal degradation of biodegradable PHBV to enhance its thermal stability. Polym. Degrad. Stab. 2009, 94, 18-24. [CrossRef]

60. Nanda, M.R.; Misra, M.; Mohanty, A.K. The Effects of Process Engineering on the Performance of PLA and PHBV Blends. Macromol. Mater. Eng. 2011, 296, 719-728. [CrossRef]

61. Du, M.; Guo, B.; Jia, D. Thermal stability and flame retardant effects of halloysite nanotubes on poly(propylene). Eur. Polym. J. 2006, 42, 1362-1369. [CrossRef]

62. Kim, B.; Do, I. Effect of viscosity ratio, rubber composition, and peroxide/coagent treatment in PP/EPR blends. J. Appl. Polym. Sci. 1996, 61, 439-447. [CrossRef] 
63. Pötschke, P.; Abdel-Goad, M.; Alig, I.; Dudkin, S.; Lellinger, D. Rheological and dielectrical characterization of melt mixed polycarbonate-multiwalled carbon nanotube composites. Polymer 2004, 45, 8863-8870. [CrossRef]

64. Yeganeh, J.K.; Goharpey, F.; Foudazi, R. Can only rheology be used to determine the phase separation mechanism in dynamically asymmetric polymer blends (PS/PVME)? RSC Adv. 2012, 2, 8116-8127. [CrossRef]

65. Dawidziuk, K. Peroxide-Initiated Modification of Polylactic Acid (PLA) and Poly (3-Hydroxyalkanoates) (PHAs) in the Presence of Allylic and Acrylic Coagents. Master Thesis, Queen's University, Kingston, ON, Canada, 2018.

66. Khan, I.; Poh, B. Natural rubber-based pressure-sensitive adhesives: A review. J. Polym. Environ. 2011, 19, 793. [CrossRef]

67. Kasatochkin, V.; Lukin, B. The Molecular Structure and Properties of Rubber. Rubber Chem. Technol. 1952, 25, 12-14. [CrossRef]

68. Fakhru'l-Razi, A.; Atieh, M.A.; Girun, N.; Chuah, T.G.; El-Sadig, M.; Biak, D.R.A. Effect of multi-wall carbon nanotubes on the mechanical properties of natural rubber. Compos. Struct. 2006, 75, 496-500. [CrossRef]

69. Bitinis, N.; Verdejo, R.; Cassagnau, P.; Lopez-Manchado, M.A. Structure and properties of polylactide/natural rubber blends. Mater. Chem. Phys. 2011, 129, 823-831. [CrossRef]

70. Yoon, L.K.; Choi, C.H.; Kim, B.K. Reactive extrusion of PP/natural rubber blends. J. Appl. Polym. Sci. 1995, 56, 239-246. [CrossRef]

71. Akbari, A.; Jawaid, M.; Hassan, A.; Balakrishnan, H. Epoxidized natural rubber toughened polylactic acid/talc composites: Mechanical, thermal, and morphological properties. J. Compos. Mater. 2014, 48, 769-781. [CrossRef]

72. Wang, X.-H.; Zhang, H.-X.; Wang, Z.-G.; Jiang, B.-Z. Toughening of poly (butylene terephthalate) with epoxidized ethylene propylene diene rubber. Polymer 1997, 38, 1569-1572. [CrossRef]

73. Yuan, D.; Xu, C.; Chen, Z.; Chen, Y. Crosslinked bicontinuous biobased polylactide/natural rubber materials: Super toughness, "net-like"-structure of NR phase and excellent interfacial adhesion. Polym. Test. 2014, 38, 73-80. [CrossRef]

74. Haneefa, A.; Bindu, P.; Aravind, I.; Thomas, S. Studies on tensile and flexural properties of short banana/glass hybrid fiber reinforced polystyrene composites. J. Compos. Mater. 2008, 42, 1471-1489. [CrossRef]

75. Sun, Y.-J.; Willemse, R.J.; Liu, T.; Baker, W.E. In situ compatibilization of polyolefin and polystyrene using Friedel-Crafts alkylation through reactive extrusion. Polymer 1998, 39, 2201-2208. [CrossRef]

76. Crompton, T.R. Physical Testing of Plastics; Smithers Rapra: Shrewsbury, UK, 2012.

77. Prospector, U.L. Polystyrene (PS) Typical Properties Generic PS (GPPS). Available online: https: / / plastics. ulprospector.com/generics/43/c/t/polystyrene-ps-properties-processing/sp/2 (accessed on 22 March 2019).

78. Database, P.P. General Purpose Polystyrene (GPPS). Available online: http://polymerdatabase.com/ Commercial\%20Polymers/PS.html (accessed on 22 March 2019).

79. Liu, G.-C.; He, Y.-S.; Zeng, J.-B.; Xu, Y.; Wang, Y.-Z. In situ formed crosslinked polyurethane toughened polylactide. Polym. Chem. 2014, 5, 2530-2539. [CrossRef]

80. Santos, R.J.d.; Agostini, D.L.d.S.; Cabrera, F.C.; Reis, E.A.P.d.; Ruiz, M.R.; Budemberg, E.R.; Teixeira, S.R.; Job, A.E. Sugarcane bagasse ash: New filler to natural rubber composite. Polímeros 2014, 24, $646-653$. [CrossRef]

81. Chuan, L.S.; Siang, L.G. Cure and Physical Characterizations of Natural Rubber Blended with Recycled Latex-Foam-Waste. Am. J. Eng. Res. (AJER) 2017, 6, 141-148.

82. Joseph, R.; George, K.; Francis, D.J. Scanning electron microscopy examination of the fracture surface of NR/SBR and NR/BR blends. Int. J. Polym. Mater. 1988, 12, 111-123. [CrossRef]

83. Wu, S. Control of intrinsic brittleness and toughness of polymers and blends by chemical structure: A review. Polym. Int. 1992, 29, 229-247. [CrossRef]

84. Deblieck, R.A.; Van Beek, D.; Remerie, K.; Ward, I.M. Failure mechanisms in polyolefines: The role of crazing, shear yielding and the entanglement network. Polymer 2011, 52, 2979-2990. [CrossRef]

85. Wu, S. A generalized criterion for rubber toughening: The critical matrix ligament thickness. J. Appl. Polym. Sci. 1988, 35, 549-561. [CrossRef]

86. Wang, Y.; Chen, K.; Xu, C.; Chen, Y. Supertoughened biobased poly (lactic acid)-epoxidized natural rubber thermoplastic vulcanizates: Fabrication, co-continuous phase structure, interfacial in situ compatibilization, and toughening mechanism. J. Phys. Chem. B 2015, 119, 12138-12146. [CrossRef] [PubMed] 
87. D'orazio, L.; Greco, R.; Mancarella, C.; Martuscelli, E.; Ragosta, G.; Silvesrte, C. Effect of the addition of ethylene-propylene random copolymers on the properties of high-density polyethylene/isotactic polypropylene blends: Part 1-Morphology and impact behavior of molded samples. Polym. Eng. Sci. 1982, 22, 536-544. [CrossRef]

88. He, J.D.; Cheung, M.K.; Yu, P.H.; Chen, G.Q. Thermal analyses of poly (3-hydroxybutyrate), poly (3-hydroxybutyrate-co-3-hydroxyvalerate), and poly (3-hydroxybutyrate-co-3-hydroxyhexanoate). J. Appl. Polym. Sci. 2001, 82, 90-98. [CrossRef]

89. George, S.; Varughese, K.T.; Thomas, S. Thermal and crystallisation behaviour of isotactic polypropylene/nitrile rubber blends. Polymer 2000, 41, 5485-5503. [CrossRef]

90. Halimatuddahliana; Ismail, $H$. The effect of dynamic vulcanization on the properties of polypropylene/ethylene-propylene diene terpolymer/natural rubber (PP/EPDM/NR) ternary blend. Polym.-Plast. Technol. Eng. 2008, 48, 34-41. [CrossRef]

91. Bartczak, Z.; Argon, A.S.; Cohen, R.E.; Weinberg, M. Toughness mechanism in semi-crystalline polymer blends: I. High-density polyethylene toughened with rubbers. Polymer 1999, 40, 2331-2346. [CrossRef]

92. Noda, I.; Satkowski, M.M.; Dowrey, A.E.; Marcott, C. Polymer alloys of Nodax copolymers and poly (lactic acid). Macromol. Biosci. 2004, 4, 269-275. [CrossRef]

93. Xu, H.; Van Deventer, J.S. Microstructural characterisation of geopolymers synthesised from kaolinite/stilbite mixtures using XRD, MAS-NMR, SEM/EDX, TEM/EDX, and HREM. Cem. Concr. Res. 2002, 32, 1705-1716. [CrossRef]

94. Kunioka, M.; Tamaki, A.; Doi, Y. Crystalline and thermal properties of bacterial copolyesters: Poly (3-hydroxybutyrate-co-3-hydroxyvalerate) and poly (3-hydroxybutyrate-co-4-hydroxybutyrate). Macromolecules 1989, 22, 694-697. [CrossRef]

95. Bai, H.; Huang, C.; Xiu, H.; Zhang, Q.; Fu, Q. Enhancing mechanical performance of polylactide by tailoring crystal morphology and lamellae orientation with the aid of nucleating agent. Polymer 2014, 55, 6924-6934. [CrossRef]

96. Zhang, H.; Zhang, Z. Impact behaviour of polypropylene filled with multi-walled carbon nanotubes. Eur. Polym. J. 2007, 43, 3197-3207. [CrossRef]

97. Bai, H.; Wang, Y.; Song, B.; Han, L. Synergistic toughening effects of nucleating agent and ethylene-octene copolymer on polypropylene. J. Appl. Polym. Sci. 2008, 108, 3270-3280. [CrossRef]

98. Hudson, S.; Smith, C.; Kaplan, D. Biopolymers from Renewable Resources; Springer Science and Business Media: New York, NY, USA, 1998; pp. 96-118.

99. Chen, Y.; Chen, K.; Wang, Y.; Xu, C. Biobased heat-triggered shape-memory polymers based on polylactide/epoxidized natural rubber blend system fabricated via peroxide-induced dynamic vulcanization: Co-continuous phase structure, shape memory behavior, and interfacial compatibilization. Ind. Eng. Chem. Res. 2015, 54, 8723-8731. [CrossRef]

100. Rolere, S.; Liengprayoon, S.; Vaysse, L.; Sainte-Beuve, J.; Bonfils, F. Investigating natural rubber composition with Fourier Transform Infrared (FT-IR) spectroscopy: A rapid and non-destructive method to determine both protein and lipid contents simultaneously. Polym. Test. 2015, 43, 83-93. [CrossRef]

101. Bousfield, G. Effect of Chain Extension on Rheology and Tensile Properties of PHB and PHB-PLA Blends; École Polytechnique de Montréal: Montréal, QC, Canada, 2014.

102. Dehkordi, M.H. Air Quality in the Museum Environment: Exemplary Investigations on Air Pollutants in Berlin, Tehran und Mumbai Museums; Hochschule für Bildende Künste: Dresden, Germany, 2015.

103. Tanaka, Y. Structural characterization of natural polyisoprenes: Solve the mystery of natural rubber based on structural study. Rubber Chem. Technol. 2001, 74, 355-375. [CrossRef]

104. Chutamas, M.; Sunthornvarabhas, J.; Sriroth, K.R. Evaluation of Gamma Radiation on NR/PHBV Blends. Appl. Mech. Mater. 2013, 300-301, 1325-1329. [CrossRef]

105. Chutamas, M.; Sunthornvarabhas, J.; Hyun, J.K.; Klanarong, S. Improving Mechanical Properties of Poly- $\beta$-Hydroxybutyrate-co- $\beta$-Hydroxyvalerate by Blending with Natural Rubber and Epoxidized Natural Rubber. Adv. Mater. Res. 2014, 983, 179-182. [CrossRef]

(C) 2019 by the authors. Licensee MDPI, Basel, Switzerland. This article is an open access article distributed under the terms and conditions of the Creative Commons Attribution (CC BY) license (http:/ / creativecommons.org/licenses/by/4.0/). 